\title{
ANALISIS KAPASITAS DAN KINERJA LALU LINTAS DI JALAN H.R. RASUNA SAID JAKARTA
}

\author{
Edmund Surya Jaya ${ }^{1}$ dan Najid ${ }^{2}$ \\ ${ }^{1}$ Program Studi Sarjana Teknik Sipil, Universitas Tarumanagara, Jl. Letjen S. Parman No.1 Jakarta \\ Edmund.325150129@stu.untar.ac.id \\ ${ }^{2}$ Program Studi Sarjana Teknik Sipil, Universitas Tarumanagara, J1. Letjen S. Parman No.1 Jakarta \\ najid@ft.untar.ac.id
}

Masuk: 12-01-2021, revisi: 04-03-2021, diterima untuk diterbitkan: 05-03-2021

\begin{abstract}
Some of the main roads in South Jakarta, one of which is Jalan H.R. Rasuna Said, which is always crowded with passing vehicles, both residents of Jakarta and Jabodetabek, traffic on Jalan HR Rasuna Said Jakarta often experiences congestion, one of the causes is the increase in the number of vehicles in the city and also traffic performance which is not matched by an increase in number. road users. The increase in the volume of traffic will cause a change in behavior towards traffic performance, based on the guidelines of MKJI 1997 (Manual of Indonesian Road Capacity) the value of road capacity is $C=6968 \mathrm{pcu} / \mathrm{km}$ with a free flow speed of Fv $=59,55$ $\mathrm{km} / \mathrm{hour}$ while the capacity Greenberg's selected model produces a capacity of $\mathrm{C}=11384 \mathrm{pcu} / \mathrm{km}$ with a free flow speed of $S f f=49,72 \mathrm{~km} /$ hour while the condition of the passing vehicle exceeds the basic capacity based on MKJI 1997, namely the maximum volume of $V=10635 \mathrm{pcu} / \mathrm{km}$ and with a speed of $S=18,25 \mathrm{~km} / \mathrm{hour}$ so that the research model that will be used as a reference for the next calculation is the Greenberg model.
\end{abstract}

Keywords: Greenshield; Greenberg; Underwood; Capacity; MKJI 1997

\begin{abstract}
ABSTRAK
Beberapa ruas jalan raya di Jakarta Selatan salah satunya adalah jalan H.R. Rasuna Said yang selalu dipadati dengan kendaraan yang melintas baik itu warga Jakarta maupun dari Jabodetabek, lalu lintas di Jalan H.R Rasuna Said Jakarta sering sekali mengalami kemacetan salah satu penyebabnya adalah peningkatan jumlah kendaraan di dalam kota dan juga kinerja lalu lintas yang tidak diimbangi oleh meningkatnya jumlah pengguna jalan. Peningkatan jumlah volume lalu lintas akan menyebabkan perubahan perilaku terhadap kinerja lalu lintas, berdasarkan pedoman MKJI 1997 (Manual Kapasitas Jalan Indonesia) nilai kapasitas ruas jalan sebesar C = $6968 \mathrm{smp} / \mathrm{km}$ dengan kecepatan arus bebas sebesar Fv $=59,55 \mathrm{~km} / \mathrm{jam}$ sedangkan kapasitas model terpilih Greenberg menghasilkan kapasitas $\mathrm{C}=11384 \mathrm{smp} / \mathrm{km}$ dengan kecepatan arus bebas Sff $=$ 49,72 km/jam sedangkan kondisi kendaraan yang melintas melebihi kapasitas dasar bedasarkan MKJI 1997 yaitu volume maksimum sebesar V = $10635 \mathrm{smp} / \mathrm{km}$ dan dengan kecepatan $\mathrm{S}=18,25 \mathrm{~km} / \mathrm{jam}$ sehingga model penelitian yang akan digunakan sebagai acuan perhitungan selanjutnya adalah model Greenberg.
\end{abstract}

Kata kunci: Greenshield; Greenberg; Underwood; Kapasitas; MKJI 1997

\section{PENDAHULUAN}

Kota administrasi Jakarta Selatan merupakan salah satu daerah yang terletak di provinsi DKI Jakarta dan sekaligus menjadi wilayah elit di Provinsi DKI Jakarta, bedasarkan data dari badan pusat statistik DKI Jakarta, diketahui adanya kepadatan penduduk yang pesat dikarenakan bukan hanya sebagai daerah permukiman tetapi juga sebagai lokasi pusat perniagaan dan perkantoran, tercatat jumlah penduduk pada tahun 2018 sebanyak 2.296.977 jiwa atau 21,94\% dari total penduduk DKI Jakarta. Jalan H.R Rasuna Said sendiri merupakan jalan protokol yang terletak di Kecamatan Menteng Jakarta Selatan, nama jalan ini diambil dari nama seorang pahlawan nasional indonesia yaitu Rasuna Said. Jalan ini membentang sepanjang 4,9 kilometer dari Menteng Jakarta Pusat sampai Tendean Mampang Prapatan Jakarta Selatan, setiap harinya kegiatan-kegiatan di Jalan Rasuna Said menghasilkan sirkulasi atau pergerakan secara terus-menerus baik pagi, siang, sore maupun malam hari. Karena merupakan salah satu jalur lalulintas dengan sirkulasi yang besar, sehingga jalan H.R Rasuna Said ini mempunyai sejumlah masalah lalu-lintas. Tingginya sirkulasi ini ditandai banyaknya jumlah kendaraan yang melintasi jalan tersebut, baik pergerakan menerus maupun pergerakan lokal yang menggunakan lahan disekitar ruas jalan tersebut. Langkah yang biasanya ditempuh 
yaitu dengan meningkatkan efisiensi penggunaan ruang jalan, mengurangi angkutan yang tidak efisien dalam penggunaan ruang jalan. Untuk itu langkah yang dilakukan yakni dengan meningkatkan kapasitas infratruktur yang ada, membatasi dan mengendalikan penggunaan kendaraan pribadi serta mendorong penggunaan angkutan umum (Iskandar, 2012).

Tujuan penelitian ini adalah sebagai berikut:

○ Untuk menentukan kapasitas jalan bedasarkan MKJI.

- Untuk menentukan kecepatan arus bebas bedasarkan MKJI.

○ Untuk membuat model hubungan kepadatan lalu lintas dan kecepatan lalu lintas.

○ Untuk mengevaluasi kapasitas dan kecepatan arus bebas bedasarkan MKJI.

○ Untuk menganalisis kinerja lalu lintas dengan berbagai kondisi.

\section{Parameter arus lalu lintas}

Terdapat beberapa variabel atau ukuran dasar yang digunakan untuk menjelaskan arus lalu lintas. Tiga variabel utama adalah volume (q), kecepatan (v), dan kepadatan (k). Variabel lainnya yang digunakan dalam analisis lalu lintas adalah headway (h), spacing (s), dan occupancy (R).

\section{Volume lalu lintas (v)}

Volume lalu lintas adalah banyaknya kendaraan yang melewati suatu titik atau garis tertentu pada suatu penampang melintang jalan.Data pencacahan volume lalu lintas adalah informasi yang diperlukan untuk fase perencanaan, desain, manajemen sampai pengoperasian jalan (Sukirman, 1994).

\section{Ekivalen Mobil Penumpang (EMP)}

Dalam rekayasa lalu lintas, arus kendaraan yang bersifat campuran karena keragaman tipe kendaraan perlu diubah dalam suatu arus yang setara dengan acuan jenis kendaraan tertentu yang dalam hal ini adalah mobil penumpang sehingga selanjutnya dinyatakan dalam satuan mobil penumpang. Dengan demikian arus dari berbagai tipe kendaraan harus diubah menjadi kendaraan mobil penumpang dengan menggunakan suatu nilai konversi yang disebut dengan ekivalensi mobil penumpang (Putranto, 2008). Nilai dari ekivalen mobil penumpang dapat dilihat pada tabel 1 .

Tabel 1. Nilai ekivalensi jenis kemdaraan (EMP)

\begin{tabular}{ccc}
\hline No. & Jenis Kedaraan & Satuan Mobil Penumpang \\
\hline 1 & Sepeda Motor & 0,3 \\
\hline 2 & Mobil Penumpang & 1 \\
\hline 3 & Truck Ringan & 1,2 \\
\hline 4 & Truck Sedang & 2,5 \\
\hline 5 & Bus & 1,2 \\
\hline 6 & Truck Berat & 3 \\
\hline (Sumber: MKJI, 1997)
\end{tabular}

\section{Kecepatan}

Kecepatan adalah jarak yang dapat ditempuh dalam satuan waktu tertentu, biasa dinyatakan dalam satuan $\mathrm{km} / \mathrm{jam}$. Pemakai jalan dapat menaikkan kecepatan untuk memperpendek waktu perjalanan, atau memperpanjang jarak perjalanan. Nilai perubahan kecepatan adalah mendasar tidak hanya untuk berangkat dan berhenti tetapi untuk seluruh arus lalu lintas yang dilalui.

\section{Kecepatan arus bebas}

Kecepatan arus bebas adalah kecepatan rata-rata teoritis $(\mathrm{km} / \mathrm{jam})$ lalu lintas pada kerapatan sama dengan nol, yaitu tidak ada kendaraan yang lewat. Kecepatan arus bebas merupakan kecepatan $(\mathrm{km} / \mathrm{jam})$ kendaraan yang tidak dipengaruhi oleh kendaraan lain (yaitu kecepatan dimana pengendara merasakan perjalanan yang nyaman, dalam kondisi geometrik, lingkungan dan pengaturan lalu lintas yang ada, pada segmen jalan dimana tidak ada kendaraan yang lain (MKJI, 1997).Penentuan kecepatan arus bebas pada kondisi sesungguhnya dapat dihitung dengan menggunakan rumus sebagai berikut:

$$
\mathrm{FV}=(\mathrm{FVo}+\mathrm{FVw}) \times \mathrm{FFV} s \mathrm{x} \text { FFVcs }
$$


dengan $\mathrm{FV}=$ kecepatan arus bebas kendaraan ringan $(\mathrm{km} / \mathrm{jam}), \mathrm{FV}_{\mathrm{O}}=$ kecepatan arus bebas dasar kendaraan ringan $(\mathrm{km} / \mathrm{jam}), \mathrm{FV}_{\mathrm{W}}=$ penyesuaian lebar jalur lalu lintas efektif $(\mathrm{km} / \mathrm{jam}), \mathrm{FFV}_{\mathrm{sf}}=$ faktor penyesuaian kondisi hambatan samping (perkalian), $\mathrm{FFV}_{\mathrm{CS}}=$ faktor penyesuaian ukuran kota (perkalian).

\section{Kepadatan (D)}

Kepadatan didefenisikan sebagai jumlah kenderaan yang menempati suatu panjang tertentu dari lajur atau jalan, dirata-ratakan terhadap waktu, biasanya dinyatakan dengan kenderaan per $\mathrm{km}(\mathrm{kend} / \mathrm{km})$. Penentuan kepadatan dapat dihitung dengan cara berikut:

$$
\mathrm{D}=\frac{\mathrm{v}}{\mathrm{s}}
$$

dengan $\mathrm{D}=$ kepadatan lalu lintas (kend/km), $\mathrm{V}=$ volume lalu lintas/kapasitas lalu lintas (kend/jam), $\mathrm{S}=$ kecepatan lalu lintas $(\mathrm{km} / \mathrm{jam}, \mathrm{m} / \mathrm{det})$.

\section{Kapasitas jalan (C)}

Kapasitas satu ruas jalan dalam satu sistem jalan raya adalah jumlah kendaraan maksimum yang memiliki kemungkinan yang cukup untuk melewati jalan tersebut (dalam satu maupun kedua arah) dalam periode waktu tertentu dan dibawah kondisi jalan dan lalu lintas yang umum, (Oglesby, C.H, 1993).Besarnya kapasitas dipengaruhi oleh kapasitas dasar, faktor penyesuaian lebar jalur lalu lintas, faktor penyesuaian pemisah arah, faktor penyesuaian hambatan samping dan faktor penyesuaian ukuran kota (MKJI, 1997).Maka penentuan kapasitas pada kondisi sesungguhnya dapat dihitung dengan rumus:

$$
\mathrm{C}=\mathrm{C}_{\mathrm{o}} \times \mathrm{FC}_{\mathrm{w}} \times \mathrm{FC}_{\mathrm{sp}} \times \mathrm{FC}_{\mathrm{sf}} \times \mathrm{FC}_{\mathrm{c}}
$$

dengan $\mathrm{C}=$ kapasitas $(\mathrm{smp} / \mathrm{jam}), \mathrm{Co}=$ kapasitas dasar $(\mathrm{smp} / \mathrm{jam}), \mathrm{FCw}=$ faktor penyesuaian lebar jalur lalu lintas, $\mathrm{FCsp}=$ faktor penyesuaian pemisahan arah, $\mathrm{FCsf}=$ faktor penyesuaian hambatan samping, $\mathrm{FCcs}=$ faktor penyesuaian ukuran kota.

\section{Hambatan samping}

Hambatan samping yakni aktivitas samping yang dapat menimbulkan konflik dan berpengaruh terhadap pergerakan arus lalu lintas serta menurunkan kinerja jalan.Adapun tipe kejadian hambatan samping adalah:

○ Jumlah pejalan kaki berjalan atau menyebrang sepanjang segmen jalan.

- Jumlah kendaraan berhenti dan parkir.

- Jumlah kendaraan bermotor yang masuk dan keluar dari lahan samping jalan dan jalan samping.

- Arus kendaraan lambat yaitu arus total (kend/jam) sepeda, becak, delman, pedate dan sebagainya.

\section{Hubungan volume, kecepatan, dan kepadatan}

Dalam hubungan antara parameter-parameter lalu lintas, terdapat 3 komponen parameter penting adalah sebagai berikut:

○ Volume (Flow) : Jumlah kendaraan yang melewati suatu titik tinjau tertentu pada suatu ruas jalan.

- Kecepatan (Speed): Jarak yang dapat ditempuh suatu kendaraan pada ruas jalan per satuan waktu.

- Kepadatan (Density): Jumlah kendaraan per satuan panjang jalan tertentu.

\section{Model hubungan karakteristik arus lalu lintas}

Studi hubungan aliran lalu lintas telah banyak dilakukan oleh para ahli transportasi, hasil studi ini dituangkan dengan model matematis. Terdapat 3 model yang dikenal antara lain:
○ Model Greenshield.
- Model Greenberg.
○ Model Underwood.

\section{Model Greenshield}

Pemodelan ini merupakan model dengan kondisi ideal (ideal state) atau tanpa gangguan dan tanpa hambatan samping, hubungan linear antara kecepatan dan kerapatan ini menjadi hubungan yang paling popular dan alam tinjauan pergerakan lalu lintas (Ofyar Tamin, 2000). Adapun persamaan hubungan kecepatan dan kepadatan adalah sebagai berikut:

$$
\mathrm{S}=S f f-\frac{S f f}{D j} \cdot D
$$


Dimana $\boldsymbol{S f f}=$ adalah kecepatan pada kondisi lalu lintas sangat rendah atau pada kondisi kepadatan mendekati nol atau kecepatan arus bebas ( $\mathrm{km} / \mathrm{jam}), \boldsymbol{D} \boldsymbol{j}=$ adalah kepadatan pada kondisi arus lalu lintas macet total $(\mathrm{kend} / \mathrm{km})$.

Adapun persamaan kondisi-kondisi lain yang dapat dipergunakan juga, sebagai contoh kondisi arus maksimum/ kapasitas (Vm), kondisi kepadatan maksimum (Dm), Kondisi kecepatan pada saat arus maksimum (Sm). Dari kondisi-kondisi tersebut dapat dicari dengan rumus sebagai berikut:

$$
\begin{aligned}
\mathrm{Vm} & =\frac{D j \times s f f}{4} \\
\mathrm{Dm} & =\frac{D J}{2} \\
\mathrm{Sm} & =\frac{S f f}{2}
\end{aligned}
$$

\section{Model Greenberg}

Hubungan ini dibuat dengan mengasumsikan bahwa arus lalu lintas mempunyai kesamaan dengan arus fluida. Pada tahun 1959 Greenberg menyelidiki aliran arus lalu lintas yang dilakukan pada bagian utara terowongan Lincoln di kota New York dan menganalisis hubungan antara kecepatan dan kerapatan dengan mempergunakan asumsi kontinuitas dari persamaan gerakan benda cair. Adapun persamaan hubungan kecepatan dan kepadatan adalah sebagai berikut:

$$
\mathrm{S}=\frac{\ln \mathrm{D}}{\mathrm{b}}-\frac{\ln \mathrm{C}}{\mathrm{b}}
$$

Adapun persamaan kondisi-kondisi lain yang dapat dipergunakan juga, sebagai berikut:

$$
\begin{aligned}
& \mathrm{Vm}=\mathrm{Sm} \cdot \mathrm{C} \cdot \mathrm{e}^{\mathrm{Sm}} \\
& \mathrm{Dm}=e^{\text {LnC-1 }} \\
& \mathrm{Sm}=-\frac{1}{b}
\end{aligned}
$$

\section{Model Underwood}

Underwood mengasumsikan bahwa hubungan matematis antara kecepatan - kepadatan bukan merupakan fungsi linear melainkan fungsi eksponensial (Ofyar Tamin, 2000). Persamaan yang menyatakan hubungan antara kecepatan dan kepadatan dapat dinyatakan sebagai berikut:

$$
\operatorname{LnS}=\operatorname{LnSff}-\frac{\mathrm{D}}{\mathrm{Dm}}
$$

Adapun persamaan kondisi-kondisi lain yang dapat dipergunakan juga, sebagai berikut:

$$
\begin{aligned}
& \mathrm{D}_{\mathrm{M}}=-\frac{1}{B} \\
& \mathrm{Sm}=e^{\text {Ln } S f f-1} \\
& \mathrm{Vm}=\frac{\text { Dm.Sff }}{e}
\end{aligned}
$$

\section{METODE PENELITIAN}

Metode yang akan digunakan dalam penelitian ini yaitu:

- Studi literatur atau perpustaakaan, dengan sumber seperti buku, jurnal-jurnal ilmiah yang ada hubungannya dengan yang akan dibahas, artikel- artikel dan sebagainya.

- Pendekatan metode survei.

- Metode survei pada jalan yang ditinjau dengan cara memperhatikan dan menghitung jumlah kendaraan yang melintas dalam kurun waktu lebih 2 jam per sesi.

- Menganalisis data pengamatan dengan membuat model aliran transportasi dan grafik hubungan antara kecepatan, kepadatan dan volume serta membuat hasil kinerja lalu lintas yang meliputi tingkat pelayanan ruas jalan tersebut.

\section{Metode pengumpulan data}

Survei yang akan dilaksanakan dengan cara pengamatan secara langsung dilokasi adalah salah satu metode primer yang mencangkup seperti kapasitas jalan, kecepatan rata-rata, volume lalu lintas. 


\section{Metode analisis statistik regresi linear}

Regresi linear adalah metode statistika yang digunakan untuk membentuk model hubungan antara variabel terikat (dependen; responden; Y) dengan satu atau lebih variabel bebas (independen; prediktor; X). Analisis regresi setidaktidaknya memiliki 3 kegunaan, yaitu untuk tujuan deskripsi dari fenomena data atau kasus yang sedang diteliti, untuk tujuan kontrol, serta untuk tujuan prediksi.

Dari variabel-variabel bebas yang digunakan untuk membentuk model regresi tersebut, bentuk persamaan regresi linear sebagai berikut:

$$
\begin{aligned}
& \mathrm{B}=\frac{N \cdot \sum(X i \cdot Y i)-\sum X i \cdot \Sigma Y i}{N \cdot \sum X i^{2}-\left(\sum X i\right)^{2}} \\
& \mathrm{Y}=\mathrm{A}+\mathrm{B} \cdot \mathrm{X}
\end{aligned}
$$

dengan $\mathrm{Y}=$ variabel hasil prediksi. $\mathrm{A}=$ konstanta kurva linear, $\mathrm{B}=$ koefisien parameter laju, $\mathrm{X}=$ pertumbuhan beban variabel.

\section{HASIL DAN PEMBAHASAN}

\section{Karakteristik lokasi penelitian}

Karakteristik ruas jalan lokasi penelitian dapat dilihat pada tabel 2 berikut ini:

Tabel 2. Karakteristik ruas jalan lokasi penelitian

\begin{tabular}{ccc}
\hline No & Uraian & Keterangan \\
\hline 1 & Lebar jalan & $17,5 \mathrm{~m}$ \\
\hline 2 & Jumlah lajur & 2 lajur 1 arah \\
\hline 3 & Tipe ruas jalan & $4 / 2 \mathrm{D}$ \\
\hline 4 & Lebar Trotoar & $1,5 \mathrm{~m}$ \\
\hline 5 & Lebar median & $1 \mathrm{~m}$ \\
\hline 6 & Lebar bahu jalan & $0,5 \mathrm{~m}$ \\
\hline 7 & Parkir pinggir jalan & Tidak ada \\
\hline 8 & Jembatan & Tersedia \\
\hline 9 & Uenyebrangan & Besar \\
\hline 10 & Tipe daerah & $\begin{array}{c}\text { Komersial dan } \\
\text { perkantoran }\end{array}$ \\
\hline
\end{tabular}

Dari data yang dapat dilihat pada tabel 2, kondisi ruas jalan yang penulis analisis hanya satu arah dan jalur cepat saja dengan tipe ruas jalan 4/2 D atau jalan satu arah tepat di depan RS MMC (Metropolitan Medical Center Hospital) dengan arah lalu lintas dari Menteng Jakarta Pusat menuju Mampang Prapatan Jakarta Selatan. Adapun lokasi data lalu lintas yang diambil dapat diakses melalui link google maps (https://www.google.com/maps/place/Metropolitan+Medical+Centre+(MMC)+Hospital/@6.234788,106.8395576, 13.33z/data=!4m5!3m4!1s0x2e69f3ef1dd2565b:0x92260e34f4f59617!8m2!3d-6.2199783!4d106.8322992) akses menuju lokasi penelitian dapat ditempuh menggunakan transportasi umum yaitu bus Transjakarta dengan turun di halte GOR Sumantri atau menggunakan transportasi lainnya yaitu taksi dan transportasi online lainnya.

Kondisi disekitar lokasi penelitian banyak gedung-gedung perkantoran dan juga pusat perbelanjaan, salah satunya gedung duta besar Malaysia dan juga RS Mayapada.

\section{Analisis EMP, volume, kecepatan dan kepadatan}

Hasil analisis volume yang sudah dikalikan dengan faktor konversi EMP dapat dilihat pada tabel 3 sampai tabel 5 berikut ini: 
Tabel 3. Data volume lalu lintas pada jam sibuk pagi

\begin{tabular}{|c|c|c|c|c|}
\hline \multicolumn{2}{|c|}{ Data Volume Per jam } & \multirow{2}{*}{$\begin{array}{l}\text { Volume } \\
\text { smp/jam }\end{array}$} & \multirow{2}{*}{$\begin{array}{c}\text { Kecepatan } \\
\text { Rata-Rata } \\
(\mathrm{km} / \mathrm{jam})\end{array}$} & \multirow{2}{*}{$\begin{array}{c}\text { Kepadatan } \\
(\mathrm{smp} / \mathrm{km})\end{array}$} \\
\hline Pagi & Waktu & & & \\
\hline Data 1 & $07.00-08.00$ & 8125,6 & 25,25 & 321,8 \\
\hline Data 2 & $07.15-08.15$ & 7996 & 24,5 & 326,4 \\
\hline Data 3 & 07.30-08.30 & 7532,5 & 25,25 & 298,3 \\
\hline Data 4 & 07.45-08.45 & 7572,2 & 27,5 & 275,4 \\
\hline Data 5 & 08.00-09.00 & 7509 & 28,25 & 265,8 \\
\hline \multicolumn{2}{|c|}{ Maksimum } & 8125,6 & 28,25 & \\
\hline \multicolumn{2}{|c|}{ Minimum } & 7509 & 24,5 & \\
\hline
\end{tabular}

Hasil analisis tabel 3, dapat dilihat bahwa terjadi kepadatan tertinggi pada jam sibuk pagi pukul 07.15-08.15 yaitu sebesar $\mathrm{D}=326,4 \mathrm{smp} / \mathrm{km}$ dengan kecepatan rata-rata $\mathrm{S}=24,5 \mathrm{~km} / \mathrm{jam}$.

Tabel 4. Data volume lalu lintas pada jam sibuk siang

\begin{tabular}{|c|c|c|c|c|}
\hline \multicolumn{2}{|c|}{ Data Volume Per jam } & \multirow[b]{2}{*}{$\begin{array}{l}\text { Volume } \\
\text { smp/jam }\end{array}$} & \multirow{2}{*}{$\begin{array}{c}\text { Kecepatan } \\
\text { Rata-Rata } \\
\text { (km/jam) }\end{array}$} & \multirow{2}{*}{$\begin{array}{l}\text { Kepadatan } \\
(\mathrm{smp} / \mathrm{km})\end{array}$} \\
\hline Siang & Waktu & & & \\
\hline Data 1 & $12.00-13.00$ & 5587,9 & 35,25 & 158,5 \\
\hline Data 2 & $12.15-13.15$ & 5954,5 & 35 & 170,1 \\
\hline Data 3 & $12.30-13.30$ & 5995,9 & 34,25 & 175,1 \\
\hline Data 4 & $12.45-13.45$ & 6149,4 & 33,75 & 182,2 \\
\hline Data 5 & $13.00-14.00$ & 6083,5 & 34 & 178,9 \\
\hline \multicolumn{2}{|c|}{ Maksimum } & 6149,4 & 35,25 & \\
\hline \multicolumn{2}{|c|}{ Minimum } & 5587,9 & 33,75 & \\
\hline
\end{tabular}

Hasil analisis tabel 4, dapat dilihat bahwa terjadi kepadatan tertinggi pada jam sibuk siang pukul 12.45-13.45 yaitu sebesar $\mathrm{D}=182,9 \mathrm{smp} / \mathrm{km}$ dengan kecepatan rata-rata $\mathrm{S}=33,75 \mathrm{~km} / \mathrm{jam}$.

Tabel 5. Data volume lalu lintas pada jam sibuk sore

\begin{tabular}{|c|c|c|c|c|}
\hline \multicolumn{2}{|c|}{ Data Volume Per jam } & \multirow{2}{*}{$\begin{array}{l}\text { Volume } \\
\text { smp/jam }\end{array}$} & \multirow{2}{*}{$\begin{array}{c}\text { Kecepatan } \\
\text { Rata-Rata } \\
(\mathrm{km} / \mathrm{jam})\end{array}$} & \multirow{2}{*}{$\begin{array}{c}\text { Kepadatan } \\
(\mathrm{smp} / \mathrm{km})\end{array}$} \\
\hline Sore & Waktu & & & \\
\hline Data 1 & $16.00-17.00$ & 9167 & 26,75 & 342,6915888 \\
\hline Data 2 & $16.15-17.15$ & 9730,3 & 24,75 & 393,1434343 \\
\hline Data 3 & $16.30-17.30$ & 9880,1 & 23 & 429,5695652 \\
\hline Data 4 & $16.45-17.45$ & 10099,6 & 20,75 & 486,7277108 \\
\hline Data 5 & $17.00-18.00$ & 10635 & 18,25 & 582,739726 \\
\hline \multicolumn{2}{|c|}{ Maksimum } & 10635 & 26,75 & \\
\hline \multicolumn{2}{|c|}{ Minimum } & 9167 & 18,25 & \\
\hline
\end{tabular}

Hasil analisis tabel 5, dapat dilihat bahwa terjadi kepadatan tertinggi pada jam sibuk sore pukul 17.00-18.00 yaitu sebesar $\mathrm{D}=582,73 \mathrm{smp} / \mathrm{km}$ dengan kecepatan rata-rata $\mathrm{S}=18,25 \mathrm{~km} / \mathrm{jam}$.

\section{Analisis kecepatan arus bebas}

Dalam Manual Kapasitas Jalan Indonesia (MKJI 1997) kecepatan arus bebas dasar kendaraan ringan dipilih sebagai kriteria dasar untuk kinerja segmen jalan pada arus sama dengan nol. Perhitungan kecepatan arus bebas di ruas jalan HR Rasuna Said selegkapnya sebagai berikut: 
Pada persamaan diatas nilai-nilai FVo, FVw, FFVsf dan FFVcs dapat dilihat pada MKJI 1997, sebagai berikut:

- $\mathrm{FV}_{0} \quad=$ kecepatan arus bebas dasar kendaraan ringan untuk jalan empat-lajur terbagi (4/2 D) $55 \mathrm{~km} / \mathrm{jam}$

$-\mathrm{FV}_{\mathrm{W}} \quad=$ penyesuain kecepatan untuk lebar jalan adalah $(4 \mathrm{~km} / \mathrm{jam})$

- $\mathrm{FFV}_{\mathrm{SF}} \quad$ = faktor penyesuain kondisi hambatan samping adalah $(0,98)$

- $\mathrm{FFV}_{\mathrm{CS}}=$ faktor penyesuain kecepatan untuk ukuran kota adalah $(1,03)$

Sehingga :

$\mathrm{FV}=\left(\mathrm{FV}_{0}+\mathrm{FV}_{\mathrm{W}}\right) \times \mathrm{FFV}_{\mathrm{SF}} \times \mathrm{FFV}_{\mathrm{CS}}=(55+4) \times 0,98 \times 1,03$ $=59,55 \mathrm{~km} / \mathrm{jam}$

Rangkuman hasil perhitungan kecepatan arus bebas $\left(\mathrm{F}_{\mathrm{V}}\right)$ dapat dilihat pada tabel 6.

Tabel 6. Analisis kecepatan arus bebas

\begin{tabular}{cccccc}
\hline Fwo & FVw & $\begin{array}{c}\text { (Fwo }+ \\
\text { FVw })\end{array}$ & FFVsf & FFVcs & FV \\
\hline 55 & 4 & 59 & 0,98 & 1,03 & 59,55 \\
\hline
\end{tabular}

Dari hasil analisis kecepatan arus bebas pada tabel 6, dapat diketahui bahwa bedasarkan manual kapasitas jalan Indonesia 1997 kecepatan arus bebas pada ruas jalan H.R Rasuna Said tepatnya pada lokasi penelitian memiliki kecepatan arus bebas sebesar Fv $=59,55 \mathrm{~km} / \mathrm{jam}$.

\section{Analisis kapasitas ruas jalan}

Dalam perhitungan kapasitas ruas jalan, langkah-langkah perhitungannya adalah menentukan nilai-nilai yang dijadikan dasar perhitugan kapasitas yaitu kapasitas dasar dan dan beberapa factor penyesaian. Berikut analisis kapasitas ruas jalan:

$\mathrm{C}=\mathrm{C}_{\mathrm{O}} \times \mathrm{FC}_{\mathrm{W}} \times \mathrm{FC}_{\mathrm{SP}} \times \mathrm{FC}_{\mathrm{SF}} \times \mathrm{FC}_{\mathrm{CS}}$

Rangkuman komponen-komponen seperti Co, FCw, FCsp, FCsf, dan FCcs dapat dilihat pada tabel 7 berikut:

Tabel 7. Analisis kapasitas ruas jalan H.R Rasuna said

\begin{tabular}{|c|c|c|c|c|c|}
\hline \multirow{2}{*}{ Co } & \multicolumn{4}{|c|}{ Faktor Penyesuaian } & \multirow{2}{*}{$\mathrm{C}$} \\
\hline & $\mathrm{FCw}$ & FCsp & FCsf & FCcs & \\
\hline 6600 & 1,08 & 1 & 0,94 & 1,04 & 6968,3328 \\
\hline
\end{tabular}

Dari hasil analisis kapasitas pada tabel 7, dapat diketahui bahwa bedasarkan manual kapasitas jalan Indonesia 1997 kapasitas pada ruas jalan H.R Rasuna Said tepatnya pada lokasi penelitian memiliki kecepatan arus bebas sebesar C $=6968,3328 \mathrm{smp} / \mathrm{km}$

\section{Contoh analisis model Greenshield jam sibuk pagi}

Contoh analisis regresi pada model Greenshield dapat dilihat pada tabel 8 dan rangkuman pada tabel 9 berikut ini:

Tabel 8. Regresi model Greenshield

\begin{tabular}{|c|c|c|c|c|c|c|}
\hline \multicolumn{2}{|c|}{ Data Volume Per jam } & \multirow{2}{*}{$\begin{array}{l}\text { Kecepatan Rata-Rata } \\
\quad(\mathrm{km} / \mathrm{jam})(\mathrm{S}=\mathrm{Y} 1)\end{array}$} & \multirow{2}{*}{$\begin{array}{c}\text { Kepadatan } \\
(\mathrm{smp} / \mathrm{km})(\mathrm{D}=\mathrm{X} 1)\end{array}$} & \multirow{2}{*}{$\mathrm{Y} 1^{\wedge} 2$} & \multirow{2}{*}{$\mathrm{X} 1^{\wedge} 2$} & \multirow{2}{*}{$\mathrm{X} 1 * \mathrm{Y} 1$} \\
\hline Pagi & Waktu & & & & & \\
\hline Data 1 & $07.00-08.00$ & 25,25 & 321,81 & 637,56 & 103559,06 & 8125,6 \\
\hline Data 2 & $07.15-08.15$ & 24,5 & 326,37 & 600,25 & 106515,65 & 7996 \\
\hline Data 3 & $07.30-08.30$ & 25,25 & 298,32 & 637,56 & 88992,93 & 7532,5 \\
\hline Data 4 & $07.45-08.45$ & 27,5 & 275,35 & 756,25 & 75819,12 & 7572,2 \\
\hline \multirow[t]{3}{*}{ Data 5} & $08.00-09.00$ & 28,25 & 265,81 & 798,06 & 70652,46 & 7509 \\
\hline & $\Sigma$ & 130,75 & 1487,65 & 3429,69 & 445539,23 & 38735,3 \\
\hline & ata-rata & 26,15 & 297,53 & & & \\
\hline
\end{tabular}


Dari data tabel 8 regresi Greenshield maka didapat nilai-nilai parameter sebagai berikut:

Tabel 9. Data hasil regresi model Greenshield

\begin{tabular}{cccccccc}
\hline $\mathrm{N}$ & $\mathrm{A}$ & $\mathrm{B}$ & $\mathrm{Sff}$ & $\mathrm{Dj}$ & $\mathrm{Dm}$ & $\mathrm{Sm}$ & $\mathrm{Vm}$ \\
\hline 5 & 43,13665348 & $-0,057092308$ & 43,14 & 755,56 & 377,78 & 21,57 & 8148,080381 \\
\hline
\end{tabular}

Dari data volume dan analisis data maka rekapitulasi dan persamaan regresi model Greenshield, Greenberg dan Underwood pada beberapa rentang waktu dapat dilihat pada tabel 10 untuk waktu pagi siang dan sore, tabel 11 untuk waktu gabungan pagi-sore adalah sebagai berikut:

Tabel 10. Rekapitulasi persamaan hubungan kecepatan dan kepadatan model Greenshield, Greenberg dan Underwood periode pagi siang sore

\begin{tabular}{cccc}
\hline \multirow{2}{*}{ Model } & \multicolumn{3}{c}{ Persamaan Model } \\
\cline { 2 - 4 } & $\mathrm{S}=43,1366-0,05709 \mathrm{D}$ & $\mathrm{S}=45,9243-0,06634 \mathrm{D}$ & $\mathrm{S}=38,6917-0,03578 \mathrm{D}$ \\
\hline Greenshield & $\mathrm{S}=122,84745-16,9865 \mathrm{Ln}$ & $\mathrm{S}=92,14127-11,19797 \mathrm{Ln} \mathrm{D}$ & $\mathrm{S}=122,28123-16,36276 \mathrm{Ln}$ \\
Greenberg & $\mathrm{D}$ & $\mathrm{D}$ & $\mathrm{D}$ \\
\hline Underwood & $\mathrm{LnS}=3,88644-0,00217 \mathrm{D}$ & $\mathrm{LnS}=3,85053-0,00192 \mathrm{D}$ & $\mathrm{LnS}=3,81549-0,00162 \mathrm{D}$ \\
\hline
\end{tabular}

Tabel 11. Rekapitulasi persamaan hubungan kecepatan dan kepadatan Model Greenshield, Greenberg dan Underwood periode pagi - sore

\begin{tabular}{cccc}
\hline Waktu & \multicolumn{3}{c}{ Persamaan Model } \\
\hline \multirow{2}{*}{ Pagi - Sore } & Greenshield & Greenberg & Underwood \\
\cline { 2 - 4 } & $\mathrm{S}=40,4533-0,0414842 \mathrm{D}$ & $\mathrm{S}=101,39537-13,04704 \mathrm{Ln} \mathrm{D}$ & $\mathrm{LnS}=3,78128-0,00156 \mathrm{D}$ \\
\hline
\end{tabular}

Persamaan-persamaan yang didapat pada analisistabel 10 dan tabel 11, dapat digunakan dalam kegiatan perhitungan selanjutnya yaitu mencari data kecepatan atau kepadatan yang berhubungan dengan persamaan regresi linear sederhana.

Setelah didapat model persamaan kecepatan dan kepadatan dalam berbagai kondisi waktu yang berbeda, maka dapat dilanjutkan untuk mencari nilai-nilai dari parameter-parameter nilai yang lainnya yaitu Dm, Sm dan Vm. Berikut rekapitulasi hasil analisis nilai parameter Dm, Sm dan Vm pada tabel 12 dan pada tabel 13 untuk periode gabungan:

Tabel 12. Rekapitulasi hasil analisis nilai Dm, Sm dan Vm periode pagi, siang dan sore

\begin{tabular}{cccccc}
\hline Model & Waktu & R2 & Dm & Sm & Vm \\
\hline \multirow{3}{*}{ Greenshield } & Pagi & 0,87678 & 377,78 & 21,57 & 8148,080381 \\
\cline { 2 - 5 } & Siang & 0,7426 & 346,14 & 22,96 & 7948,161 \\
\cline { 2 - 5 } Greenberg & Sore & 0,9856 & 540,72 & 19,34 & 10460,76 \\
\cline { 2 - 6 } & Pagi & n.a & 508,519 & 16,98 & 8638,01 \\
\cline { 2 - 6 } & Siang & n.a & 1378 & 11,19 & 15430,83 \\
\cline { 2 - 6 } Underwood & Sore & 0,8466 & 647,5 & 16,36 & 10595,72 \\
\cline { 2 - 6 } & Pagi & 0,0391 & 172,09 & 18,29 & 8447,72 \\
\cline { 2 - 6 } & Siang & n.a & 520,66 & 17,66 & 9197,51 \\
\cline { 2 - 6 } & Sore & 0,8113 & 617,28 & 17,06 & 10541,42
\end{tabular}

Dapat dilihat pada tabel 12 bahwa nilai faktor determinasi $\mathrm{R}^{2}$ terbaik terdapat pada model Greenshield pada waktu sore dengan nilai $\mathrm{R}^{2}=0,9856$. Dengan nilai $\mathrm{Dm}=540,72 \mathrm{smp} / \mathrm{km}, \mathrm{Sm}=19,34 \mathrm{~km} / \mathrm{jam}$ dan juga $\mathrm{Vm}=10460,76$ $\mathrm{smp} / \mathrm{km}$. Dengan begitu maka model acuan yang dapat digunakan untu perhitungan periode pagi, siang dan sore dapat menggunakan model dari analisis Greenshield. 
Tabel 13. Rekapitulasi hasil analisis nilai Dm, Sm dan Vm periode pagi, siang dan sore

\begin{tabular}{|c|c|c|c|c|c|}
\hline Model & Waktu & $\mathrm{R} 2$ & $\mathrm{Dm}$ & $\mathrm{Sm}$ & $\mathrm{Vm}$ \\
\hline Greenshield & \multirow{3}{*}{ Pagi - Sore } & 0,9216 & 487,58 & 20,23 & 9862,12 \\
\hline Greenberg & & 0,98149 & 872,27 & 13,04 & 11384,82 \\
\hline Underwood & & 0,9585 & 642,19 & 16,13 & 10364,9 \\
\hline
\end{tabular}

Dari hasil analisis data gabungan pada tabel 13 , didapat nilai $\mathrm{R}^{2}$ terbaik yaitu pada model Greenberg sebesar $\mathrm{R}^{2}=$ 0,98149 sehingga model Greenberg dapat menjadi acuan dalam perhitungan selanjutnya.

\section{Grafik model hubungan kecepatan dan kepadatan}

Hasil dari analisis model hubungan kecepatan dan kepadatan, maka dapat dituangkan kedalam grafik hubungan kecepatan dan kepadatan, grafik yang akan ditampilkan hanya grafik pada periode gabungan data pagi - sore. Hasil perhitungan model Greenshield dapat dilihat pada grafik 1, untuk model Greenberg pada grafik 2 dan model Underwood pada grafik 3 sebagai berikut:

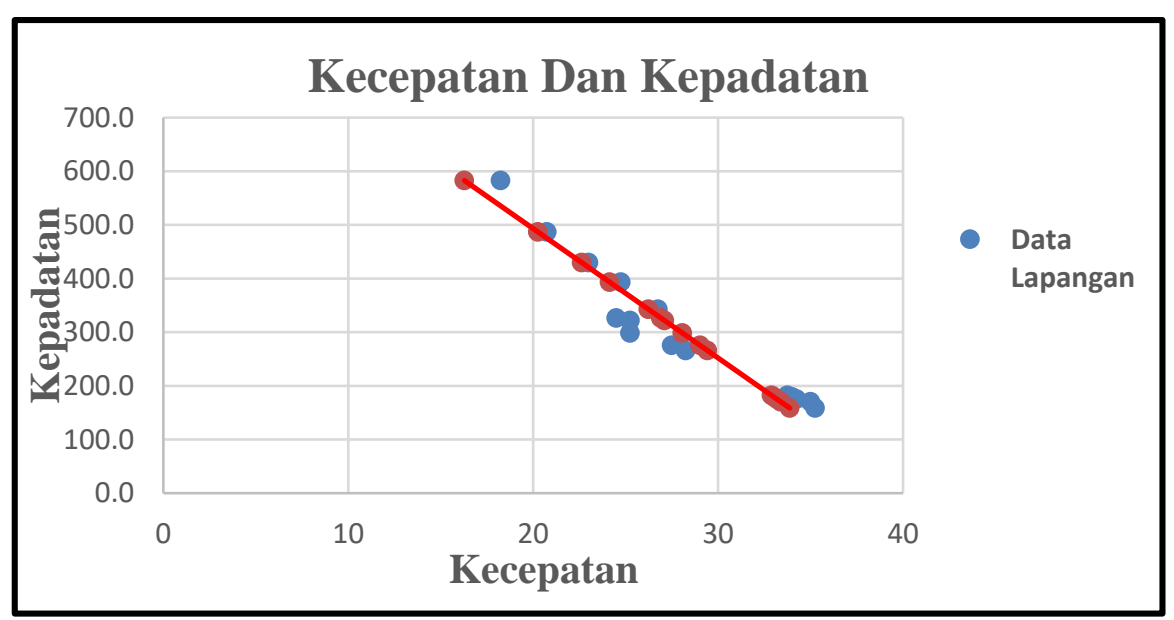

Grafik 1. Hubungan kecepatan dan kepadatan Greenshield periode data gabungan

Dari data grafik 1 hasil analisis data gabungan menunjukan model Greenshield menghasilkan garis lurus yang linear, dengan data lapangan yang tidak terlalu menyimpang terhadap data dari model.

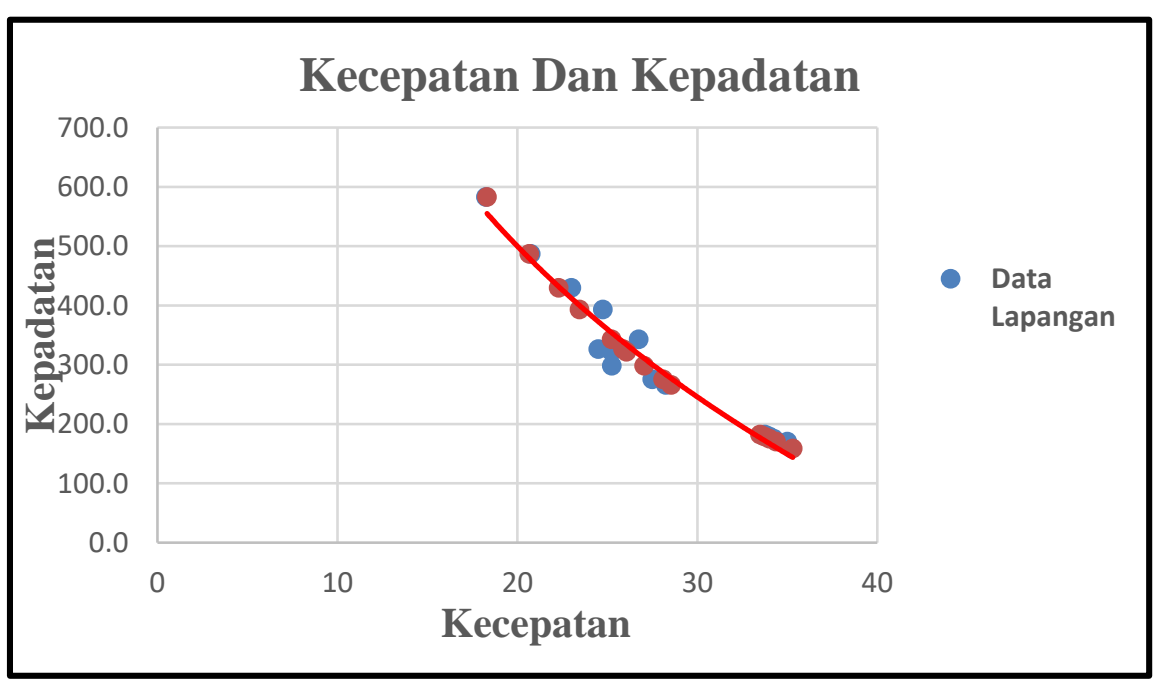

Grafik 2. Hubungan kecepatan dan kepadatan Greenberg periode data gabungan 
Dari data grafik 2 hasil analisis data gabungan menunjukan model Greenberg menghasilkan garis parabola, hal ini disebabkan karena model Greenberg merupakan model perhitungan dengan metode logaritmik dan juga data lapangan yang tidak terlalu menyimpang terhadap data dari model.

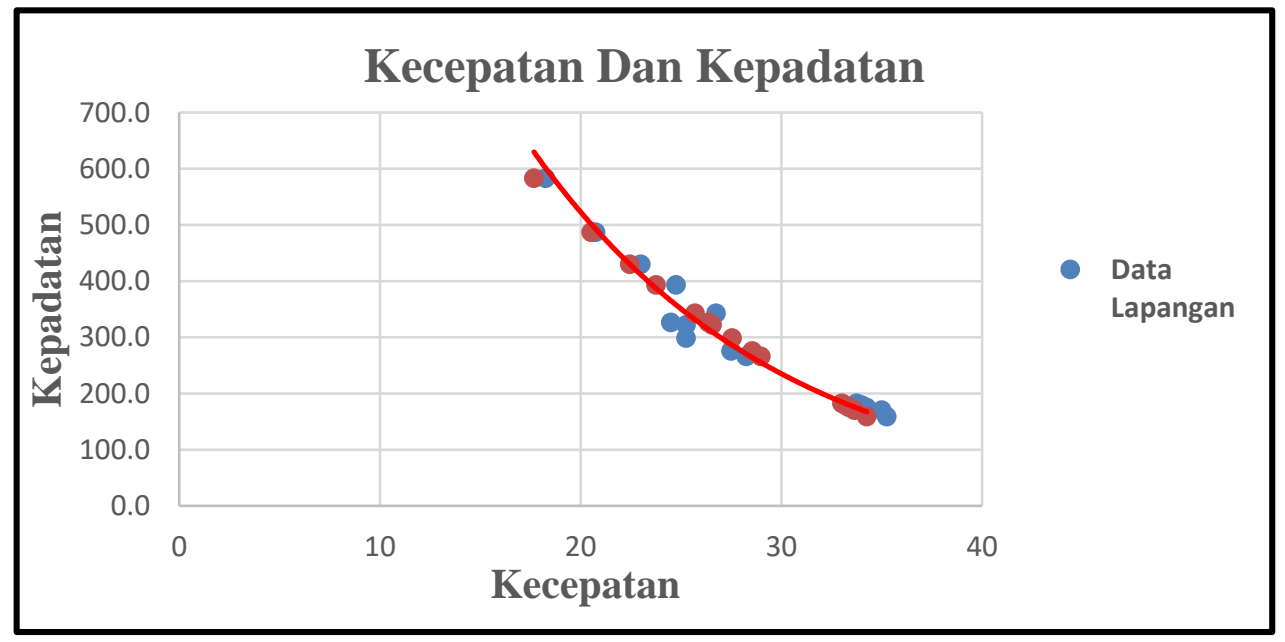

Grafik 3. Hubungan kecepatan dan kepadatan Underwood periode data gabungan

Dari data grafik 3 hasil analisis data gabungan menunjukan model Underwood menghasilkan garis parabola, hal ini disebabkan karena model Underwood merupakan model perhitungan dengan metode exponensial dan juga data lapangan yang tidak terlalu menyimpang terhadap data dari model.

\section{Evaluasi model terbaik periode pagi, siang dan sore}

Pemilihan model terbaik ini dimaksudkan untuk mendapatkan model terbaik untuk dapat dipergunakan sebagai acuan perhitungan kinerja lalu lintas pada ruas jalan yang dipilih. Pemilihan ini dilakukan dengan cara membandingkan beberapa model dengan volume aktual serta MKJI. Hasil dari perhitungan pada periode jam sibuk pagi ini yaitu terpilih model pendekatan Greenshield dari ketiga model lainnya, dengan faktor determinasi $R^{2}=0,88$ dan juga kapasitas yang mendekati volume aktual di lapangan di banding kapasitas dasar MKJI. Hasil lengkapnya analisis dapat dilihat pada tabel 14 berikut.

Tabel 14. Evaluasi model terbaik periode pagi $07.00-09.00$

\begin{tabular}{cccccc}
\hline Model & $\mathrm{R}^{2}$ & $\begin{array}{c}\text { Kapasitas } \\
\text { model } \\
(\mathrm{smp} / \mathrm{km})\end{array}$ & $\begin{array}{c}\text { Kapasitas } \\
\text { MKJI } \\
(\mathrm{smp} / \mathrm{km})\end{array}$ & $\begin{array}{c}\text { Volume } \\
\text { aktual } \\
(\mathrm{smp} / \mathrm{km})\end{array}$ & $\begin{array}{c}\text { Model } \\
\text { terpilih }\end{array}$ \\
\hline Greenshield & 0,88 & 8148,08 & 6968,33 & 8125,6 & $\checkmark$ \\
\hline Greenberg & n.a & 8638,01 & 6968,33 & 8125,6 & $X$ \\
\hline Underwood & 0,04 & 8447,72 & 6968,33 & 8125,6 & $X$ \\
\hline
\end{tabular}

Dapat dilihat pada tabel 14 model Greenshield mendominasi model terbaik pada periode pagi, dengan nilai $\mathrm{R}^{2}$ terbesar dan juga kapasitas mendekati volume aktual lapangan. Untuk evaluasi model terbaik periode lainnya dapat dilihat pada tabel 15 untuk periode pukul 12.00-14.00, dan juga tabel 16 untuk periode pukul 16.00-18.00.

Tabel 15. Evaluasi model terbaik periode siang $12.00-14.00$

\begin{tabular}{cccccc}
\hline Model & $\mathrm{R}^{2}$ & $\begin{array}{c}\text { Kapasitas } \\
(\mathrm{smp} / \mathrm{km})\end{array}$ & $\begin{array}{c}\text { Kapasitas } \\
\text { MKJI } \\
(\mathrm{smp} / \mathrm{km})\end{array}$ & $\begin{array}{c}\text { Volume } \\
\text { aktual } \\
(\mathrm{smp} / \mathrm{km})\end{array}$ & $\begin{array}{c}\text { Model } \\
\text { terpilih }\end{array}$ \\
\hline Greenshield & 0,74 & 7948,16 & 6968,33 & 6149,4 & $\checkmark$ \\
\hline Greenberg & n.a & 15430,83 & 6968,33 & 6149,4 & $X$ \\
\hline Underwood & n.a & 9197,51 & 6968,33 & 6149,4 & $X$ \\
\hline
\end{tabular}


Dapat dilihat bahwa pada tabel 15 model Greenshield mendominasi model terbaik pada periode siang, dengan nilai $\mathrm{R}^{2}$ terbesar dan juga kapasitas mendekati volume aktual lapangan.

Tabel 16. Evaluasi model terbaik periode siang $16.00-18.00$

\begin{tabular}{cccccc}
\hline Model & R2 & $\begin{array}{c}\text { Kapasitas } \\
(\mathrm{smp} / \mathrm{km})\end{array}$ & $\begin{array}{c}\text { Kapasitas } \\
\text { MKJI } \\
(\mathrm{smp} / \mathrm{km})\end{array}$ & $\begin{array}{c}\text { Volume } \\
\text { aktual } \\
(\mathrm{smp} / \mathrm{km})\end{array}$ & $\begin{array}{c}\text { Model } \\
\text { terpilih }\end{array}$ \\
\hline Greenshield & 0,99 & 10460,77 & 6968,33 & 10635 & $\checkmark$ \\
\hline Greenberg & 0,85 & 10595,72 & 6968,33 & 10635 & $X$ \\
\hline Underwood & 0,81 & 10541,42 & 6968,33 & 10635 & $X$ \\
\hline
\end{tabular}

Dapat dilihat bahwa pada tabel 16 model Greenshield mendominasi model terbaik pada periode sore, dengan nilai $\mathrm{R}^{2}$ terbesar dan juga kapasitas mendekati volume aktual lapangan.

Sedangkan model terbaik pada periode gabungan dapat dilihat pada tabel 17, yaitu periode gabungan pukul 07.0018.00 .

Tabel 17. Evaluasi model terbaik periode gabungan $07.00-18.00$

\begin{tabular}{cccccc}
\hline Model & $\mathrm{R}^{2}$ & $\begin{array}{c}\text { Kapasitas } \\
(\mathrm{smp} / \mathrm{km})\end{array}$ & $\begin{array}{c}\text { Kapasitas } \\
\text { MKJI } \\
(\mathrm{smp} / \mathrm{km})\end{array}$ & $\begin{array}{c}\text { Volume } \\
\text { aktual } \\
(\mathrm{smp} / \mathrm{km})\end{array}$ & $\begin{array}{c}\text { Model } \\
\text { terpilih }\end{array}$ \\
\hline Greenshield & 0,92 & 9862,12 & 6968,33 & 10635 & $X$ \\
\hline Greenberg & 0,98 & 11384,82 & 6968,33 & 10635 & $\checkmark$ \\
\hline Underwood & 0,96 & 10364,9 & 6968,33 & 10635 & $X$ \\
\hline
\end{tabular}

Dapat dilihat bahwa terdapat perbedaan hasil terbaik pada periode gabungan dengan periode jam sibuk pagi, siang dan sore, pada periode gabungan justru model terbaik adalah Greenberg dengan nilai $\mathrm{R}^{2}=0,98$ dengan kapasitas $\mathrm{C}$ $=11.382,82 \mathrm{smp} / \mathrm{km}$ terbesar dan juga mendekati volume aktual, hal ini menandakan model pendekatan Greenberg dapat digunakan sebagai acuan model untuk perhitungan kinerja lalu lintas ruas jalan H.R. Rasuna Said.

\section{Evaluasi kecepatan arus bebas ruas Jalan Rasuna Said}

Dari hasil analisis bedasarkan Manual Kapasitas Jalan Indonesia (MKJI, 1997) pada ruas jalan Rasuna Said didapat nilai kecepatan arus bebasnya adalah Fv $=54,9505 \mathrm{~km} / \mathrm{jam}$. Kecepatan arus bebas ini harus dievaluasi dengan hasil dari model perhitungan matematis yang menggunakan data aktual dilapangan. Hasil dari analisis tersebut dapat dilihat pada tabel 18 dan pada tabel 19 untuk data periode gabungan.

Tabel 18. Evaluasi kecepatan arus bebas menggunakan metode pendekatan Greenshield, Greenberg dan Underwood

\begin{tabular}{cccc}
\hline \multirow{2}{*}{ Periode } & Metode & $\begin{array}{c}\text { Kecepatan arus bebas } \\
\text { model }(\mathrm{km} / \mathrm{jam})\end{array}$ & $\begin{array}{c}\text { Kecepatan arus bebas } \\
(\mathrm{FV}) \text { MKJI (km/jam) }\end{array}$ \\
\hline \multirow{3}{*}{ Pagi } & Greenshield & 43,14 & 59,5546 \\
\cline { 2 - 4 } & Greenberg & n.a & 59,5546 \\
\cline { 2 - 4 } Siang & Underwood & 49,74 & 59,5546 \\
\cline { 2 - 4 } & Greenshield & 45,92 & 59,5546 \\
\cline { 2 - 4 } & Greenberg & n.a & 59,5546 \\
\hline \multirow{2}{*}{ Sore } & Greenshield & 38,02 & 59,5546 \\
\cline { 2 - 4 } & Greenberg & n.a & 59,5546 \\
\cline { 2 - 4 } & Underwood & 46,39 & 59,5546 \\
\hline
\end{tabular}


Tabel 19. Lanjutan evaluasi kecepatan arus bebas menggunakan metode pendekatan Greenshield, Greenberg dan Underwood

\begin{tabular}{cccc}
\hline Periode & Model & $\begin{array}{c}\text { Kecepatan arus bebas model } \\
(\mathrm{km} / \mathrm{jam})\end{array}$ & $\begin{array}{c}\text { Kecepatan arus bebas (FV) } \\
\text { MKJI (km/jam) })\end{array}$ \\
\hline \multirow{2}{*}{$\begin{array}{c}\text { Data Gabungan } \\
\text { pagi - sore }\end{array}$} & Greenshield & 40,45 & 59,5546 \\
\cline { 2 - 4 } & Underwood & n.a & 59,5546 \\
\hline
\end{tabular}

Pada tabel 18 dan tabel 19 evaluasi kecepatan arus bebas dengan menggunakan model pendekatan Greenshield, Greenberg dan Underwood didapat bahwa model Underwood dengan periode pagi yaitu Sff $=49,74 \mathrm{~km} / \mathrm{jam}$. Ini berarti bahwa kondisi ruas jalan H.R Rasuna Said dapat masuk kondisi kepadatan minimum atau sama dengan nol dengan kecepatan 49,74 km/jam.

\section{Rasio V/C pada hasil analisis dengan model terpilih}

Rasio V/C ini dimaksudkan untuk mengetahui rasio perbandingan antara volume aktual dengan kapasitas maksimum model yang dipilih. Angka rasio ini berada berkisar $0-1$, bila hasil rasio mendekati 1 maka ruas jalan H.R Rasuna Said sudah jenuh dan mudah terjadi kemacetan. Analisis selengkapnya dapat dilihat pada tabel 20.

Tabel 20. Rasio V/C

\begin{tabular}{|c|c|c|c|c|c|}
\hline Periode & $\begin{array}{c}\text { Volume } \\
\text { maksimum } \\
\text { (smp/jam) }\end{array}$ & $\begin{array}{c}\text { Kecepatan } \\
(\mathrm{km} / \mathrm{jam})\end{array}$ & $\begin{array}{c}\text { Kapasitas } \\
\text { dasar MKJI } \\
(\mathrm{smp} / \mathrm{km})\end{array}$ & $\begin{array}{c}\text { Kapasitas } \\
\text { model terpilih } \\
(\mathrm{smp} / \mathrm{km})\end{array}$ & Rasio V/C \\
\hline \multirow{2}{*}{ Pagi } & 8125,6 & 25,25 & 6968,33 & - & 1,166 \\
\hline & 8125,6 & 25,25 & - & 11384,82 & 0,714 \\
\hline \multirow{2}{*}{ Siang } & 6149,4 & 33,75 & 6968,33 & - & 0,882 \\
\hline & 6149,4 & 33,75 & - & 11384,82 & 0,54 \\
\hline \multirow{2}{*}{ Sore } & 10635 & 18,25 & 6968,33 & - & 1,526 \\
\hline & 10635 & 18,25 & - & 11384,82 & 0,934 \\
\hline
\end{tabular}

Dari hasil analisis pada tabel 20, lebih relavan menggunakan kapasitas dari model yang dipilih karena rasio V/C masih berada dibawah 1 artinya kondisi jalan masih dalam kondisi tidak jenuh namun dapat terjadi penumpukan kendaraan.

\section{KESIMPULAN DAN SARAN}

\section{Kesimpulan}

Berdasarakan hasil analisis pada bab sebelumnya, maka dapat disimpulkan sebagai berikut:

1. Volume maksimum periode pagi pukul 07.00 - 09.00 pada ruas jalan Rasuna Said terjadi pada pukul 07.00 - 08.00 yaitu sebesar 8125,6 smp/jam sehingga kepadatan lalu lintas sebesar 321,8 smp/km, dengan kecepatan kendaraan rata-rata sebesar $25,25 \mathrm{~km} / \mathrm{jam}$.

2. Hubungan kecepatan dan kepadatan di ruas jalan Rasuna Said dengan hasil akhir hubungan matematis antara kecepatan dan kepadatan pada data pagi - sore menggunakan model Greenshield dimana semakin tinggi kecepatan maka semakin rendah kepadatan dengan persamaan model $\mathrm{S}=40,4533-0,04148$ dan model Greenberg dengan nilai $\mathrm{S}=101,39$ - 13,047 LnD, sedangkan Underwood dengan nilai Lns = 3,7812 - 0,00156.D

3. Pada Jalan Rasuna Said model Greenberg merupakan model terbaik untuk dapat dipergunakan sebagai acuan perhitungan dan dengan nilai $\mathrm{R}^{2}=0,98$.

4. Pada analisis model periode pagi, siang dan sore. Model yang di dapat adalah Greenshield, namun hasil analisis menggunakan data gabungan pagi - sore model yang di dapat adalah Greenberg, hal ini menunjukan bahwa kondisi Jalan H.R Rasuna Said berada dalam gangguan jika di lihat secara keseluruhan dan oleh karena itu tidak dapat dipergunakan model linear Greenshield. 
5. Bedasarkan hasil analisis kapasitas menggunakan MKJI 1997 didapat kapasitas C =6968,3328 smp/km, hasil ini menunjukan bahwa bedasarkan MKJI 1997 nilai kapasitas yang dapat ditampung oleh ruas jalan adalah sebesar $\mathrm{C}=6968,3328 \mathrm{smp} / \mathrm{km}$.

6. Bedasarkan hasil analisis kecepatan arus bebas menggunakan MKJI 1997 didapat Fv = 59,55 km/jam, hasil ini menunjukan bahwa bedasarkan MKJI 1997 nilai kecepatan arus bebas yang terjadi pada ruas jalan H.R Rasuna Said adalah sebesar $59,55 \mathrm{~km} / \mathrm{jam}$.

\section{Saran}

Adapun saran dari penelitian ini adalah sebagai berikut:

1. Untuk penelitian berikutnya, secara khusus perlu dibentuk tim surveyor agar lebih fokus dalam mengambil data untuk mengurangi kesalahan-kesalahan dalam pengambilan data.

2. Perlu melakukan survei lalu lintas satu hari penuh untuk mendapatkan lebih banyak variasi kondisi lalu lintas.

\section{DAFTAR PUSTAKA}

Abubakar, Iskandar. Manajemen Lalu Lintas. Jakarta: Trasindo Gastama, 2012.

Departemen Pekerjaan Umum. Manual Kapasitas Jalan Indonesia. Direktorat Jenderall Bina Marga. 1997. Jakarta. Oglesby, C. H. Teknik Jalan Raya. Jakarta: Erlangga, 1993.

Putranto, L. S. Rekayasa Lalu Lintas. Jakarta: Indeks, 2008.

Sukirman, S. Dasar-Dasar Perencanaan Geometrik Jalan Raya. Bandung: Nova, 1994.

Tamin, O. Z. . Perencanaan dan Permodelan Transportasi. Bandung: Edisi Kedua Jurusan Teknik Sipil Institut Teknologi Bandung, 2000. 
